\title{
The Level of Readiness among Rural School Teacher in Improving the Language Skills of Preschool Children by Using the Multimedia
}

\author{
Mohd Jasmy Abd Rahman*, Macliffton Tembak Sinau, Nur Kamariah Ensimau \\ Faculty of Education, The National University of Malaysia, Bangi, Malaysia
}

Received August 2, 2020; Revised October 7, 2020; Accepted October 30, 2020

\section{Cite This Paper in the following Citation Styles}

(a): [1] Mohd Jasmy Abd Rahman, Macliffton Tembak Sinau, Nur Kamariah Ensimau, "The Level of Readiness among Rural School Teacher in Improving the Language Skills of Preschool Children by Using the Multimedia," Universal Journal of Educational Research, Vol. 8, No. 11A, pp. 71 - 77, 2020. DOI: 10.13189/ujer.2020.082109.

(b): Mohd Jasmy Abd Rahman, Macliffton Tembak Sinau, Nur Kamariah Ensimau (2020). The Level of Readiness among Rural School Teacher in Improving the Language Skills of Preschool Children by Using the Multimedia. Universal Journal of Educational Research, 8(11A), 71 - 77. DOI: 10.13189/ujer.2020.082109.

Copyright $\bigcirc 2020$ by authors, all rights reserved. Authors agree that this article remains permanently open access under the terms of the Creative Commons Attribution License 4.0 International License

\begin{abstract}
All children have their right to go to school and learn regardless of who they are. Having an education helps people to access all of their other human rights. Therefore, Ministry of Education in Malaysia made early childhood education compulsory. Literacy development has contributed to the knowledge in early childhood education. In the age of digital technology, 21st century learning is an era of change and innovation in education. Rural preschools in Malaysia have shown their dedication to make 21st century learning a prime medium in increasing literacy. The use of multimedia during preschool children's learning sessions is more interactive by relying on the integration of various media including audio, video, graphics and others to enhance children's language development. This research objective is to find out the level of readiness of pre-school teachers in the development of early childhood literacy based on 21st century learning. The questionnaire has been distributed to 30 samples of respondents in third grade rural primary school teachers in Kapit District, Sarawak was selected randomly. The findings of this study showed that teachers in rural areas are ready to apply the multimedia in teaching literacy. Hence, it is hoped that the findings of this study will assist certain parties, especially the Malaysian Ministry of Education to conduct special training in order to solve the problems that occur in rural primary schools.
\end{abstract}

Keywords 21st Century Learning, Inner Preschool, Multimedia Approach, Literacy Development, Preschool
Teacher

\section{Introduction}

The National Pre-School Standards (KSPK) curriculum implemented in 2010 was revised in 2017 to meet the new policy requirements under the Malaysian Education Development Plan (PPPM) 2013-2025 and current requirements. The review was conducted to ensure that the quality of the curriculum implemented in preschools is in line with international standards (KSPK, 2017). Teachers play an important role in determining the level of development of children [32]. Teaching and learning methods are an activity that plays a role in bringing about changes for students [22]. Effective, meaningful and enjoyable preschool and learning experience can provide children with the skills, confidence and positive attitude for future learning.

According to [2], the paradigm shift in education has been initiated through the Early Education Development Report 2013-2015 (PPPM 2013-2015) launched by the Prime Minister on September 11, 2012, providing eleven shifts expected to be implemented within 13 years. In addition, all eleven paradigm shifts are intended to enable educational transformation based on needs and aspirations in making education an agent of change to meet the 
challenges of the 21st century. To ensure that all levels of education are transformed, pre-school education is also emphasized in the drafting of the KSPK 2017 by integrating knowledge, skills and values, incorporating 21st Century Skills and applying High Level Thinking Skills (EAT) in integrating the six milestones in the KSPK 2017 framework which is Communication, Spirituality, Attitude and Values, Humanities, Physical and Aesthetic Development, Science and Technology and Personal Skills.

The first objective, set out in the KSPK 2017, is for children to use language to communicate effectively. According to [2], most children master the concept of language through informal learning experiences. This informal learning experience is embedded in preschool education. Learning a language through physical games, for example, helps children associate words with pictures or objects to understand the concept of meaning [2]. According to [27], preschool education emphasizes the 'learning through play' approach or also known as 'fun play'. In addition, through this process children will be exploring, discovering and building experiences naturally. Based on 21st century learning in line with the current era of digital technology, the multimedia approach in the classroom can enhance early childhood literacy development in preschool. Studies on early childhood literacy have contributed greatly to knowledge. Researchers such as $[13,34]$ emphasize that students should master reading comprehension at the simplest or basic level before being exposed to higher reading levels [25].

\section{Problem Statement}

Collaborative teaching and learning culture require stimulation that enables students to enjoy a field [25]. In achieving early childhood education goals, good language proficiency in the field of language is highly emphasized, but it has been shown that this is not prioritized in the pedagogical process in kindergarten or preschool [3]. Most preschool teachers find that the use of children's language is very limited and as such, they will not take into account children's language proficiency. In fact, language proficiency greatly affects preschoolers' performance in classroom learning.

According to the statement of [35], the concept of development in line with the teaching practices outlined in the KSPK is still not fully realized or not adequately practiced by teachers. Due to the lack of teachers' understanding of pedagogical and teaching practices, they hindered the effectiveness of teaching and learning processes in early childhood education as intended in preschool education.

Malaysia is a country that is moving towards a developed nation [3]. Rapid advances in science and technology, critical thinking skills and effective communication skills are essential in 21st century learning [40]. Teaching and learning of the 21st Century has different features to the education of the past [14]. 21st Century Learning has a huge impact on the education system in Malaysia [29]. According to a study conducted by [16], interview results with nine preschool teachers were involved, there were several teaching and learning weaknesses identified. These are based on the direct observation from the study of [38], having shown that the way teachers teach is so tedious that children become bored in teaching and learning sessions. The use of teaching aids is not fully utilized. This was supported by [1] who have used Ngalim's (1990) statement in [22] argue that the reason for children's loss of attention during learning is due to the way teachers explain and use boring teaching materials.

Reference [39] states that, apart from the use of teaching aids, other factors that lead to children's mastery of literacy are ways of teaching and learning that are less sensitive to children's features. Most educators today still use traditional teaching patterns that are more of a didactic approach to teaching and learning [30,33]. To date, the most frequently used activity for teachers in reading instruction is personal training $[24,29]$.

According to $[19,31]$ state that there are ineffective strategies in teaching teachers due to lack of proper knowledge and training in the process of educating and at the same time less evaluating the effectiveness of their teaching. More worrying is that the background of the training and practice received by these teachers does not seem to affect their pedagogical values directly in the classroom [34]. If preschool teachers do not use the specific approach proposed in preschool education or early childhood education, preschool children's learning needs will not be met [12]. If this is not taken into account, these factors can affect the reputation of a teacher.

In Malaysia the issue of pupils lacking literacy and numeracy skills has existed since the beginning of the Malaysian education system and became more critical in the 1960s [24,7,9,22] further pointed out that poor reading ability will affect student achievement in all subjects. According to him, students who are struggling with reading and comprehension skills will also have problems in the academic field. This is supported by the findings [13], having shown that children who do not have good reading skills will have trouble understanding other subjects. [30] also stated that weakness in language learning will affect pupils' progress in other subjects as language is a communication tool for learning all kinds of knowledge.

According to a study conducted by [36], children interviewed expressed less enjoyment in the teaching and learning process of reading in the classroom. When there is a lack of fun in the classroom, the children will lose focus and cause the children to become bored and lack the literacy skills they are trying to apply. 


\section{Research Question}

I. What is the teacher's level of readiness towards the effectiveness in using a multimedia?

II. What is the teacher's readiness level of multimedia aspects of the development of children's language skills?

III. What is the significant between teacher's readiness levels by demographic features and age?

\section{Literature Review}

\subsection{Multimedia}

In general, multimedia is related to the use of more than one type of media to convey information [38]. For example, video and music are multimedia forms because they convey information, audio or voice and video is used. Unlike music recordings that use only audio or voice and are referred to as mono-media. Multimedia is a word of multi and media. Multi comes from Latin, meaning many or many. Media also comes from the Latin word medium meaning intermediary or something used to transmit, convey or convey information. Multimedia is a combination of several elements, such as text, graphics, sound, video and animation that produce amazing animations. Multimedia also has a high degree of interactive communication. Multimedia is a combination of data or media to convey something very interesting. For computer or smartphone users it can be interpreted as information that can be conveyed through audio or video, text, graphics and animation.

It can be said that multimedia is a combination of data or media to convey information more interestingly. Multimedia is a combination of computer and video or Multimedia is generally a combination of three elements, namely voice, image and text or Multimedia is a combination of at least two media inputs or outputs from data, media can audio (voice or music), animation, video, text, graphics and images or Multimedia is a tool that delivers dynamic and interactive information that incorporates text, graphics, animation, audio and video images. Multimedia using a computer or smartphone is for creating and incorporating text, graphics, audio, motion pictures (video and animation).

\subsection{Learning Multimedia}

The term multimedia used in education today can be described as a computer system in which all media; text, graphics, audio or voice, animation and video are all in a program that explains or illustrates educational topics. Multimedia programs designed specifically for educational needs need to be taken seriously in order for the program to be fully utilized or to meet educational needs [26]. The development of multimedia programs or approaches in 21st century education now benefits both quantity and quality for teachers and students. Many researchers say that the teaching and learning process will be more effective if implemented in informal settings such as the use of multimedia in learning. The elements implemented in learning are more entertaining and will have a more positive impact.

Reference [26] states that multimedia learning is a combination of text, art, sound, animation, and video delivered to a person (child or student) with computers and electronic and digital equipment such as smartphones. Through the integration of these media, learning experiences become interactive and reflect the experience of everyday life. Reference [36] added that multimedia learning is an element designed and developed using several programs through computer software used to convey learning resources, how to use, train and so on. These elements are also based on other elements that help to attract attention, such as pictures, colours, music and animations. On the other hand, [6] found that media is practical and applicable for science learning process at elementary school level. By learning an interesting and contextual problem based thru media will improve student's thinking skill. [6] student with specific learning difficulties will be able to learn independently in more fun environment. [23]

\section{Methodology}

\subsection{Research Design}

Based on this prospective study, the answers to this question are from teachers' perceptions of the effectiveness of multimedia use in enhancing pedagogical practices of in-school pre-school teachers and thus helping to improve early childhood literacy skills. In addition, the measurement will provide quantitative data which will then be interpreted through analysis and finally generalized to meet the needs of the larger population but has similar characteristics especially in the context of studies involving the practice of pedagogy of preschool teachers.

The quantitative design according to [5] carries the meaning, the number which refers to the discrete number that is precisely stated. Quantitative research is a form of study that uses statistics as well as numerical with measurable parameters aimed at improving the relationship between educational theories and the development of teacher professionalism [7]. This could be related to the study of researchers who want to improve the pedagogical practices of preschool teachers in the interior through 21st-century learning that can help to improve early literacy skills of preschool children.

Therefore, the researcher has chosen a quantitative study designed by conducting a survey method using a set 
of questionnaires. The justification of designing the study was based on [9], who stated that the quantitative approach is more structured, has less degree of ambiguity, has a clearer meaning, is linear, has clear scheduling and is focused on the data. Survey study according to [5] is a research method that involves collecting data from a population to understand a current situation of the population and one or more variables. He added that researchers are also interested in getting a large group opinion on an issue or problem. It is thus clear that the choice of survey method in this study is to examine the perception of third-grade pre-school teachers on the effectiveness of using multimedia approaches in improving their pedagogical practices.

\subsection{Location and Sample}

This study was conducted among 30 national preschools around Kapit district, Sarawak. The schools involved were from third-level rural schools. Based on the population size of the study area, sample size is determined by reference to [5] sample size. The sample selection is based on the purpose of sampling which is the sample of this study consisting of third-grade pre-school teachers in Kapit district, Sarawak.

\section{Findings}

\subsection{The Teachers' Level of Readiness towards the Effectiveness in Using a Multimedia}

Researchers analyzed 10 questions about Teacher Readiness Levels of knowledge from the questionnaire form provided. The findings were analyzed based on feedback provided by the respondents. Respondents were required to answer these questions on a likert scale represented by Very Not Ready (STS), Not Ready (TS), Low Ready (KS), Ready (B) and Very Ready (SB).

Based on Table 1, the sixth question shows the average mean is at the highest level (4.11). This indicates that teachers are ready to motivate pre-schoolers to learn about multimedia. The first question shows that the mean is at the lowest level (3.91) indicating that teachers are less prepared to learn about preschool multimedia development.

Table 1. Min and Std deviation on level of teachers readiness on effectiveness of multimedia

\begin{tabular}{rcccc}
\hline No & Statement & Mean & Std Deviation \\
\hline 1. & I am excited to learn about the development of preschool multimedia. & 3.91 & .709 \\
2. & I am ready to use multimedia in preschool. & 4.01 & .635 \\
3. & I am prepared to increase student motivation during multimedia use. & 4.00 & .595 \\
4. & I am ready to use various multimedia methods among preschoolers. & 4.03 & .617 \\
\hline 5. & I look forward to increase student mastery in multimedia development. & 4.05 & .634 \\
6. & I want to motivate pre-schoolers to learn about multimedia. & 4.11 & .590 \\
7. & I am ready to analyse the achievement of preschool students by their level of & 3.96 & .621 \\
8. & achievement. & 4.07 & .621 \\
9. & I would like to take a Multimedia course to improve knowledge. & 4.00 & .649 \\
10. & I would like to share my knowledge of the use of multimedia among Preschool. & 4.04 & .673 \\
\hline
\end{tabular}

Table 2. Minimum Analysis and Standard deviation of the Teacher Readiness Levels from Multimedia Use Aspects in Developing Children's Language Skill

\begin{tabular}{|c|c|c|c|}
\hline No & Statement & Mean & Std Deviation \\
\hline 1. & I am ready to learn how to handle the multimedia for pre-school student. & 4.08 & .612 \\
\hline 2. & $\begin{array}{c}\text { I am ready to clearly understand the multimedia and the use of it in increasing student } \\
\text { language skills. }\end{array}$ & 4.02 & .599 \\
\hline 3. & I am ready to understand and encourage student to use a multimedia. & 3.94 & .640 \\
\hline 4. & I am ready to use multimedia to increase my language proficiency. & 3.97 & .628 \\
\hline 5. & I am ready to apply the use of multimedia while teaching is being implemented. & 3.98 & .646 \\
\hline 6. & I would like to understand how multimedia is used in improving children's language skills. & 4.00 & .613 \\
\hline 7. & I am willing to refer to the Learning Standard when preparing RPHs related to multimedia. & 4.05 & .602 \\
\hline 8. & I am ready to teach using multimedia approaches to improve children's language development. & 4.08 & .599 \\
\hline 9. & $\begin{array}{c}\text { I would like to share my understanding with other teachers about the use of multimedia in } \\
\text { improving children's language skills. }\end{array}$ & 4.04 & .609 \\
\hline 10. & I look forward to applying multimedia learning strategies in preschool. & 4.11 & .603 \\
\hline
\end{tabular}




\subsection{The Teacher's Readiness Levels of Multimedia Aspects of the Development of Children's Language Skills}

In this aspect the researchers analyzed 10 questions about the level of Teacher. This is an analysis made based on the feedback based on likert scale represented by Very Not Ready (STS), Not Ready (TS), Uncertain (KS), Ready (B) and Very Ready (SB).

Based on Table 2, the tenth question shows the highest mean was (4.11). This shows that they are ready to apply multimedia learning strategies in preschool. The third question shows that the lowest mean (3.94) indicated that teachers still do not yet understand how to motivate students when using multimedia.

The hypothesis of the study was to look at the differences and relationships between variables. The hypotheses were developed to measure differences in teacher readiness according to demographic characteristics, to measure differences in teacher readiness according to demographic characteristics and to determine the relationship between teacher readiness level and teacher readiness with multimedia use in preschool. The results are presented in detail as follows:

\section{Ho1 There Is No Significant Difference Between Teachers' Readiness Levels by Demographic Features.}

In this study, there are five demographic characteristics namely gender, age, academic qualification, term of service and school category, then five separate tests are conducted and the results are as follows: -

Table 3. $\mathrm{t}$ - test about student readiness based on gender

\begin{tabular}{|c|c|c|c|c|c|}
\hline Gender & $\mathrm{N}$ & Mean & $\begin{array}{c}\text { Std } \\
\text { Deviation }\end{array}$ & $\mathrm{t}$ & Significan \\
\hline Male & 9 & 3.91 & 5.66 & .138 & 0.019 \\
\hline Female & 21 & 3.90 & 4.66 & .138 & \\
\hline
\end{tabular}

According to [5], t-test is used to test significant differences between the two groups. It is used to test the difference between the mean of one variable for two groups of non-dependent samples. In this study, the mean between the two variables will be compared. The "p" value was used as 0.05 to determine a significant level for testing the null hypothesis, for which there was a significant difference in the level of teacher integrity in terms of gender demographics.

The t-test analysis in Table 5, below shows the mean scores of male and female teacher readiness scores. The data show that there are differences in the level of integrity between male and female teachers. This could be explained by the mean male mean score was $3.91(\mathrm{~N}=131$, SP = 5.66) and the mean score for female was $3.90(\mathrm{~N}=229$, SP $=4.66)$. The difference between the two mean scores is very small which is 0.01 . The study found $\mathrm{p}=0.019 \mathrm{>}$ 0.05 . The null hypothesis is successfully accepted and it can be concluded that the level of readiness of male teachers with female teachers shows significant differences.

\section{Ho2 There was no significant difference between the levels of teacher readiness by age.}

Table 4. ANOVA Levels of Teacher Readiness by age

\begin{tabular}{ccccc}
\hline & Df & Mean & F & Significant \\
\hline Between Group & 4 & .340 & 1.342 & .254 \\
In group & 355 & .253 & & \\
\hline
\end{tabular}

One-way ANOVA results in Table 4 showed no significant mean score difference $[\mathrm{F}=1.342(\mathrm{DK}=4,355)$ and Sig. $\mathrm{P}=0.254$ ] between teacher readiness level and age at $\mathrm{P}>0.05$. This value is very high to indicate any significant tendency. It can be said that there is no significant difference in the level of teacher readiness based on age.

\section{Ho3 There was no significant relationship between teacher readiness and multimedia use in preschool}

Table 5. Correlation of Teacher Readiness Levels with Multimedia being used in Preschools

\begin{tabular}{ccc}
\hline Variable & Multimedia Used \\
\hline Level of Readiness & $\begin{array}{c}\text { Coloration } \\
\text { values( } \mathrm{r} \text { ) } \\
\text { Significant } \\
\text { Values ( })\end{array}$ & $.788^{* *}$ \\
& .000 \\
\hline
\end{tabular}

$\mathrm{N}=360, \mathrm{P}<0.01$

Based on Table 5, it is found that the correlation coefficient, $r$ for the level of readiness with multimedia use in preschool is equal to $0.788 * *$. This shows a high correlation. Since the value of $\mathrm{p}=0.000$ is smaller than 0.05 , this hypothesis fails to be accepted. This means that there is a significant relationship between the level of readiness and the use of multimedia in preschool. Because the correlation test results show a significant relationship, it can be concluded that there is a significant relationship between the level of readiness and the use of multimedia in rural preschool teachers in Kapit District.

\section{Discussion}

Through this study, researchers hope to find out the level of teachers' readiness for the effectiveness of multimedia use in improving the pedagogical practices of preschool teachers. The purpose of this study is to determine teachers' perceptions of the use of multimedia in improving preschool children's language skills. In line with the era of the Industrial Revolution 4.0 (4IR), teachers in rural primary schools also respond to the demands of the current educational cycle. It is also hoped that this study will be $\square$ able to identify the constraints faced by preschool teachers on the implementation of multimedia approaches during teaching and learning in the classroom as well as 
understanding the need for interior preschool teachers to implement multimedia approaches. Researchers hope that through this study, they will be able to identify in-house pre-school teachers who are skilled in implementing multimedia approaches and teachers who master the approach to multimedia in preschool. It is hoped that the findings of this study will assist certain parties, especially the Ministry of Education, Malaysia in solving problems that occur in rural primary schools.

\section{Conclusions}

21st Century Learning (PAK21) is a study based on the development of science and technology [31]. These digital literacy skills are the skills of using digital technology to solve a single problem [4]. These skills are also closely linked to 21st century learning. This skill combines the use of technology to communicate information, communicate and develop digital materials [13]

Awareness of the importance of education, including preschool education in rural schools, is very high. Through education, we can create knowledgeable and highly skilled human capital to continue the survival and development of our nation. In line with the explosion of information technology and communication in the digital age of 21st century learning, the implementation of multimedia approaches in preschools by teachers, especially as teaching and learning (PdP) methods to promote early literacy development in school children, is encouraged. This is because Generation $\mathrm{Z}$ is more receptive to change in terms of innovation. The multimedia approach certainly has a positive impact on the PdP process and is well-suited to children's interests and the demands of today's educational development. The multimedia approach, which is the 21st century learning approach, is very effective in inducing positive changes in children's behavior and attitudes towards learning, furthering the development of early literacy. Moreover, this approach is simple and flexible to integrate into the teaching process as activities to achieve specific learning objectives.

\section{REFERENCES}

[1] Adenan Ayob. 2017. The Impact of Learning Through the Use of Web-Based Interactive Reading Materials on Children's Reading Comprehension. Journal of Early Childhood Education, 6: 1-17.

[2] Aliza Ali \& Zamri Mahamod. 2016. Development and Usability Module-Based Learning Play For Malay Language Skills Preschool Children. Malay Education Journal, 6 (1): 16-29. Anida Sarudin, Dahlia Janam, Zulkifli Osman, Ahmad Khair Mohd Noor. 2016. Possession Malay Child Preschool Skills Evaluation Planned Based Inventory. Faculty of Language and Communication, Sultan Idris
University of Education.

[3] Azizi Jaafar, Tuan Majdiah Tuan Ismail \& Mohd Zaki Abd Rahim. 2018. The Role of Social Media in 21st Century Education. Darulaman Seminar 2018 National Level. Darulaman Campus Teacher Education Institute. 392-405.

[4] Badusah, J., Nordin. N, Nor, N. F. M., Hassan, K. H., Abdullah, M. Ab Aziz, M. J., Hanafiah, M. M., Norman, H, Mohammad, W.M.R. W., Kamrozzaman., N. A. 2017. UKM 21st Century TrModel: Developing Transdisciplinary Research Skills For 21st Century Graduates. Transdisciplinary Education Seminar (STEd2017), 1-8.

[5] Chua Yan Piaw. 2014. Research Methods and Statistics: Research Methods Third Edition. Selangor

[6] Farida Nur Kumala, Dwi Agus Setiawan, Mohamad Amin, Muhana Gipayana, Rifka Atul Karvilla. 2019. Universal Journal of Educational Research Vol. 7(9), pp. 1964 - 1969 DOI: 10.13189/ujer.2019.070916

[7] Ghazali Darusalam \& Sufean Hussin. 2018. Research Methodology in Research: Practice and Analysis of Second Edition Studies. Kuala Lumpur: University of Malaya.

[8] Giang F. 2013. Gamification and Learning: A Review of Issues and Research. Journal of e Learning and Knowledge Society. 1 (1): 212-215.

[9] Hanita. L, \& Shamsuddin. F. 2018. 21st Century Teaching and Learning Practices. Sandakan Offset Percentakan Sdn. Bhd: Sandakan.

[10] Hasliza Hashim, Siti Munira Mohd Nasri \& Zarina Mustafa. 2016. Challenges Faced by Teachers in the Implementation of Frog Virtual Learning Environment in the Classroom. Asia Pacific Journal of Educators and Education, 31: 115-129.

[11] Ismail MA-A, Mohammad JA-M. 2017. Kahoot: A Promising Tool for Formative Assessment in Medical Education. Education in Medicine Journal. 2017; 9 (2): 19 26

[12] Jain Chee, Mariani Md Nor, Abdul Jalil Othman \& Mohd Nzari Abdul Rahman. 2018. Content Knowledge Issues, Pedagogy and Technology Among Preschool Teachers. Journal of Curriculum and Education Asia Pacific, 6 (1): 7-21.

[13] Jamaludin Badusah, Nurul Aisyah Kamrozzaman, Wan Muna Ruzanna Wan Mohammad. 2017. Learning transdisciplinary approach in upholding the Malay language of the 21st Century. International Conference Upholding Bahasa Melayu 5th. Sultan Idris Education University. 322-328.

[14] Mahaya Salleh \& Zakaria Mohd Arif. 2018. Level of 21st Century Teaching and Learning Practices of Sik District Secondary School Teachers. Darulaman Seminar 2018 National Level. Darulaman Campus Teacher Education Institute. 348-353.

[15] Megaliong, P. D. (2016). Interior Design Creative Collaborative Space in Surabaya. Intra, 4 (2): 814-823.

[16] Miehelle M. Neumann. 2018. Using Tablets and Apps to Enhance Emergent Literacy Skills in Young Children. Early Childhood Research Quarterly, 42: 239-246. 
[17] Ministry of Education Malaysia. 2013. Malaysia Education Development Plan 2013-2025: Preschool to Post-Secondary Education. Putrajaya: Ministry of Education Malaysia (MOE).

[18] Ministry of Education Malaysia. 2017. National Preschool Standard Curriculum. Putrajaya: Ministry of Education Malaysia (MOE).

[19] Mohd Jasmy Abd Rahman \& Md. Yusoff Daud | 2015. Information Technology Promotion and Market: 21st Century Empowerment. Selangor, Malaysia. Faculty of Education UKM.

[20] Mohd Jasmy Abd Rahman \& Norazani Md Zain. 2017. IT In 21st Century Education. Bangi. Faculty of Education UKM.

[21] Mohd Jasmy Abd Rahman et. al. 2016. Social Media: 21st Century Learning. Selangor, Malaysia. Faculty of Education UKM.

[22] Mohd Shahidan Ilyas \& Khadijah Abdul Razak. 2018. Simulation-Based Learning (PBS) as a 21st Century Islamic Education Teaching Method. Proceeding of The 11th International Workshop and Conference of Asian Studies in Linguistics, Islamic anad Arabic Education, Sosial Sciences and Educational Technology 2018. Faculty of Education Universiti Kebangsaan Malaysia. 318-328.

[23] Noor Aini Ahmad 2020. Problem Based Prezi Multimedia: Elementary School Students' Thinking Skill. Universal Journal of Educational Research Vol. 8(6), pp. 2641 - 2645 DOI: 10.13189/ujer.2020.080647

[24] Noor Hayati Che Mat. 2017. The level of skills for the 21st Century Pedagogy in Teaching and Learning of English, Books Proceedings of the National Seminar, Best Educational Practices

[25] Nor Ruzila Ramly \& Kamisah Osman. 2018. Application of Mind Map as Teaching Aids in 21st Century Learning for Year Four Science Subjects. E-Proceedings of Science \& Psychology Education 2018. Universiti Kebangsaan Malaysia. 270-279.

[26] Nurul Ain Binti Azmi, Razzatul Iza Zurita \& Norazila. 2018. Use of KAHOOT Application in Learning Theory Module in Ledang Johor Community College. International Conference on Education, Islamic Studies \& Socil Sciences Research.

[27] Ramlah Bt. Male, Nor Afni Bt. Resad \& Siti Fathimah Az-Zahra Bt. Mohd. Fauzi. 2016. Entertainment Education Activities Among Preschool Teachers in Gombak District. Journal of Early Childhood Education, 5: 19-29

[28] Rashidah Elias, Mahizer Hamzah \& Mahani Razali. 2017. Appropriateness of Smart Book Development for Nursery Early Childhood Reading Skills. National Journal of Early Childhood Education, Special Issue: 32-47.
[29] Rasidah Ramdan \& Nik Mohd Rahimi Nik Yusoff. 2018. Levels of Teachers' Concern for 21st Century Learning Innovation. Darulaman Seminar 2018 National Level. Darulaman Campus Teacher Education Institute. 66-71.

[30] Saifulnizan Che Ismail. 2018. Teachers and ICT Applications in 21st Century PdPc Education Magazine.

[31] Siti Aisyah Mohd Firdaus \& Mohd Mahzan Awang. 2017. The Use of Technology in the Teaching and Learning of History. Proceedings-Kuala Lumpur International Communication Education, Lenguage and Social Sciences 8 (KLiCELS 8). Universiti Kebangsaan Malaysia. 176-185.

[32] Siti NurAin Zakaria \& Suziyani Mohamed. 2018. Preschool Teachers' Knowledge of Children's Fine Motor Development. Darulaman Seminar 2018 National Level. Darulaman Campus Teacher Education Institute. 38-43.

[33] Siti Sumiyati \& Surjono, H.D. 2014. Development of Learning Multimedia to Improve the Past Mastery of French Students. Journal of Educational Technology Innovation. Vol.1 No.2: 199-211.

[34] Suppiah Nachiappan, Zaharah Osman, Nurulhuda Md Hassan, Norly Jamil, Hashimah Hussein, Mastura Othman \& Sandra Suffian. 2018. An Analysis of The Criteria and Effectiveness of Using Teaching Aids in Preschool Science and Technology Components in Malaysia. International Journal of Academic Research in Progressive Education and Development, 7 (1): 63-82.

[35] Suppian Nachiappan, Rachel Mildred Edward Munovah, Norazilawati Abdullah, Sandra Suffian. 2017. Cognitive Development in Preschool Children Through Play Techniques. Journal of Early Childhood Education, 6: 34-44.

[36] Suripno \& Abdul Gafur. 2015. Development of Multimedia Learning Agrarian Law in the Citizenship Education and FIS Law Study Program UNY. Journal of Educational Technology Innovation.Vol.1 No.2. ISSN: 2460-7177: 105-114.

[37] Syed Lamsah \& Syed Chear. 2017. Apply 21st Century Skills in Preschool. Education Magazine.

[38] Vika Dyah Wijayanti, Endah Hendarwati \& Aris Setiawan. 2017. Improve Reading Ability in Children in Group A by Using Picture Card Cards. Journal of Early Childhood and Early Childhood Education, 3: 43-52.

[39] Widyaning Hapsari, Lisnawati Ruhaena \& Wiwien Dinar Pratisti. 2017. Improvement of Early Literacy Ability of Preschoolers Through Stimulation Programs. Journal of Psychology, 44 (3): 177-184.

[40] Wong Weng Siong, Kamisah Osman. 2018. Learning Based Games in STEM Education and 21st Century Mastery. Polytechnic \& Community College Journal of Sciences and Humanities, Vol 3, 121 